\title{
The Interpretation of Second Temple Judaism as "Spätjudentum" in Christian Biblical Scholarship
}

The notion of "Spätjudentum” (i.e., "late Judaism”) as a term for Second Temple Judaism, or parts of it, was prominent in biblical scholarship from about 1870 to 1970. ${ }^{1}$ It entailed the idea that Judaism as a theologically legitimate entity came to an end with the emergence of Christianity and openly expressed an antisemitic facet of Christian biblical scholarship. We will see, however, that the origins of this notion are also driven by a Kantian philosophy of history. In addition, the idea was also influenced by some common traits of modern antisemitism, especially in the late nineteenth and early twentieth centuries. The notion of "Spätjudentum" is a partial mirror of how Western Christianity perceived Judaism in the nineteenth and twentieth centuries, as expressed, for instance, by Friedrich Schleiermacher:

Der Judaismus ist schon lange eine tote Religion, und diejenigen, welche jetzt noch seine Farbe tragen, sitzen eigentlich klagend bei der unverweslichen Mumie. ${ }^{2}$

[Judaism has long been a dead religion, and those still wearing its colors are in fact sitting in lament next to the mummy which does not decay.]

Schleiermacher's position may now seem clearly outdated, but it is helpful to remember the (still widespread) portrayal of Hebrew as a dead language developed by early modern philology, especially by people like Johann David Michaelis (1717-1791), who viewed Hebrew by analogy to Latin and Greek as if no contemporaneous, living Judaism existed. ${ }^{3}$

1 Cf. U. Kusche, Die unterlegene Religion: Das Judentum im Urteil deutscher Alttestamentler (Berlin: Institut für Kirche und Judentum, 1991).

2 F. D. E. Schleiermacher, Über die Religion: Reden an die Gebildeten unter ihren Verächtern (Studienausgabe; Zürich: TVZ, 2012), 237. On Schleiermacher and his position regarding the Hebrew Bible and Judaism, see R. Smend, "Schleiermachers Kritik am Alten Testament," in Epochen der Bibelkritik: Gesammelte Studien, ed. R. Smend (Munich: Kaiser, 1991), 3:128-44; M. Blum, "Ich wäre ein Judenfeind?" Zum Antijudaismus in Friedrich Schleiermachers Theologie und Pädagogik (Vienna: Böhlau, 2010).

3 Cf. M. C. Legaspi, The Death of Scripture and the Rise of Biblical Studies (Oxford: Oxford University Press, 2011).

Ә OpenAccess. () 2020 Konrad Schmid, published by De Gruyter. (cc) BY-NC-ND This work is licensed under the Creative Commons Attribution-NonCommercial-NoDerivatives 4.0 License. 


\section{Terminology}

Oddly enough, the German terms "Spätjudentum" and "Frühjudentum" ["early Judaism"] are designations for the same period, each applying with slight differentiation to the Second Temple period. If one looks up "Spätjudentum" in the Theologische Realenzyklopädie, there is a cross-reference to "Frühjudentum," so what formerly was addressed as "Spätjudentum" is now "Frühjudentum." On the other hand, in the Historisches Wörterbuch philosophischer Grundbegriffe published between 1971 and 2007, there is an entry on "Spätjudentum" that does an excellent job reflecting on the category's problems and shortcomings-but there is no entry on "Frühjudentum." ${ }^{5}$ The reason is not because the lexicon still prefers "Spätjudentum” over "Frühjudentum," but because "Spätjudentum" is a loaded concept that has its own history.

The shift from "Frühjudentum" to "Spätjudentum" in twentieth-century scholarship is observable in the name of the book series "Ancient Judaism and Early Christianity," published by Brill. The publisher's current website informs us that the series began in 1976 as "Arbeiten zur Geschichte des antiken Judentums und des Urchristentums" ["Works on the History of Ancient Judaism and Early Christianity"]. But that is not the full truth. Despite being silenced by Brill's website, the history of the series goes back even further to 1961. At that time, the name of the series was "Arbeiten zur Geschichte des Spätjudentums und Urchristentums" ["Works on the History of Late Judaism and Early Christianity"]. In 1968, the title was changed to "Arbeiten zur Geschichte des späteren Judentums und des Urchristentums" ["Works on the History of Later Judaism and Early Christianity"]; in 1970, it was changed again to "Arbeiten zur Geschichte des antiken Judentums" ["Works on the History of Ancient Judaism”]; and finally in 2005, with a shift into English, it was changed to "Ancient Judaism and Early Christianity." What is now termed "Ancient Judaism" was formerly called "Spätjudentum," then "späteres Judentum," and finally "antikes Judentum."

In German-speaking contexts from the 1890s until the 1970s, "Spätjudentum" was a much more common term than "Frühjudentum," " with very few ex-

4 "Frühjudentum," in Theologische Realenzyklopädie, ed. G. Krause and G. Müller (Berlin: De Gruyter, 1971-1983), 31:605.

5 M. Ritter, "Spätjudentum," in Historisches Wörterbuch der Philosophie, ed. J. Ritter et al. (Basel: Schwabe, 1971-2007), 9:1312-15.

6 The following observations are based on bibliographical search results of Google's Ngram Viewer. A few randomly chosen examples include G. Kittel, Die Probleme des palästinischen Spätjudentums und das Urchristentum (Stuttgart: Kohlhammer, 1926); G. Hölscher, Urgemeinde und Spätjudentum (Oslo: Dybwad, 1928); E. Gaugler, "Das Spätjudentum," in Mensch und Got- 
amples of the former appearing after 1970. Its occurrences after 1970 are in texts like this one that discuss the concept in the history of scholarship. Since the midtwentieth century, both "Frühjudentum" and "Antikes Judentum" have been on the rise but in a more modest way.

In English-speaking contexts, "late Judaism" never managed to establish itself as a fully recognized term, being found only sparsely in the secondary literature. ${ }^{7}$ Similarly, the proposal by Gabriele Boccaccini to speak of "Middle Judaism" has not won the day. ${ }^{8}$ Unlike the parallel terms in German scholarship, "ancient Judaism" is more common in English than "early Judaism," but both terms are widely used and recognized.

In the same general timeframe of German discussed above, one sees in French-speaking contexts a widespread use of "judaïsme tardif," but since the 1980s, the more common term has been "judaïsme ancien.” Quite a few appearances of "judaïsme tardif" are in texts that were translated from German." French scholarship seems not to have produced an equivalent to "early Judaism."

In Italian-speaking contexts, the picture is significantly different. Here there is widespread use of "tardo giudaismo," which seems still to be the most common designation. While "antico giudaismo" is a possible formulation, it seems uncommon. Once again, it is striking that some occurrences of "tardo giudaismo" are in texts that have either been translated from German or have been motivated by German scholarship. ${ }^{10}$

Accordingly, we can confidently trace the origins of the term "late Judaism" back to the German-speaking realm, from which it spread into other languages.

theit in den Religionen: Kulturhistorische Vorlesung gehalten im Wintersemester (Bern: Paul Haupt, 1943), 277-313; H. Bietenhard, Die himmlische Welt im Urchristentum und Spätjudentum (Tübingen: Mohr Siebeck, 1950); J. Jervell, Imago Dei: Gen 1,26f. im Spätjudentum, in der Gnosis und in den paulinischen Briefen (Göttingen: Vandenhoeck \& Ruprecht, 1960).

7 See for instance T. L. Donaldson, "Levitical Messianology in Late Judaism: Origins, Development, and Decline,” Journal of the Evangelical Theological Society 24 (1981): 193-207.

8 G. Boccaccini, Middle Judaism: Jewish Thought 300 B.C.E to 200 C.E. (Minneapolis: Fortress, 1991).

9 Cf. O. Cullmann, Le milieu johannique: étude sur l'origine de l'evangile de Jean, sa place dans le judaïsme tardif, dans le cercle des disciples de Jésus et dans le christianisme primitif (Geneva: Labor et Fides, 1976).

10 F. Parente, "Escatologia e politica nel tardo giudaismo e nel cristianesimo primitivo," Rivista Storica Italiana 80 (1968): 234-96; L. Rosso Ubigli, “Alcuni aspetti della concezione della "porneia' nel tardo giudaismo,” Henoch 1 (1979): 201-45; H. Ringgren, Israele: i padri, l'epoca dei re, il giudaismo (Milano: Edizione Jaca, 1987), 338: “Caratteristiche generali del tardo ebraismo. La legge." 


\section{The Early Usage of the Term "Spätjudentum" for Designating Pre-Christian Judaism in the Late Eighteenth Century}

The term "Spätjudentum" was coined by Karl Heinrich Ludwig Poelitz (17721838), who served as a professor of Ethics and History in Dresden. In his 1794 Latin dissertation from Leipzig, De gravissimis theologiae seriorum Judaeorum decretis quorum vestigia in libris inde ab exilii aetate usque ad saeculi quarti post c.n. initia deprehenduntur, he applied the term "seriores Judaei" ("later Jews") to the period from the exile to the fourth century C.E. "Seriores Judaei" seems to be an original formulation of his. In previous literature, the main categories were "Judaei antiqui" and "Judaei recentiores." 11 A year later, Poelitz published a book entitled Pragmatische Uebersicht der Theologie der spätern Juden, ${ }^{12}$ which deals with the era of Judaism immediately prior to Christianity. On page xiv, Poelitz explains why he undertakes this project:

Doch dieses wichtige Zeitalter der jüdisch-religiösen Kultur interessiert uns auch deswegen, weil das Christentum [...] aus dieser Religion hervorging, und doch, wenn es die Bedürfnisse seiner Zeit befriedigen sollte, sich an die damals herrschenden Begriffe und Vorstellungen anschließen musste. [...] Aus diesem philosophischen Gesichtspuncte habe ich den nun die religiöse Kultur der spätern Juden zu fassen gesucht.

[This important era of Jewish-religious culture is therefore interesting for us, since Christianity [...] went forth from this religion [...] Since it needed to satisfy the needs of its time, it had to connect to the concepts and ideas of that time [...] Coming from this philosophical perspective, I analyzed the religious culture of the later Jews.]

Several elements of Poelitz's motivation and approach become clear from this quote. Having been trained as a philosopher and not as a historian or Semitist, he approaches the subject in terms of a Kantian philosophy of history. And in order to understand the emergence of Christianity from this philosophical ap-

11 Cf. J. Morin de Blois, Commentarius historicus de disciplina in administratione sacramenti Poenitentiae tredecim primis seculis in ecclesia occidentali, ...Hic inserta sunt quae Judaei antiqui et recentiores tradunt de Poenitentia (Metelen: Frederici, 1682); Also A. Georg Wähner still uses this opposition in 1743 (Antiquitates Ebraeorum de Israeliticae gentis [Göttingen: Vandenhoeck \& Ruprecht, 1743], e.g., 134, 224).

12 K. H. L. Poelitz, Pragmatische Uebersicht der Theologie der spätern Juden (Leipzig: Feind, 1795). 
proach to history, he analyzes the concepts and ideas of Judaism from the preceding times. In his own words:

Diese pragmatische Darstellung der spätern jüdischen Theologie ist nun übrigens nicht zunächst deswegen begonnen und angestellt worden, um das eigentliche jüdische Lehrgebäude und ihre Dogmatik darzustellen (was uns als Christen izt in dem Zeitalter einer höhern Kultur wenig interessiren würde), sondern vorzüglich deswegen, um die in unserem Zeitaltern begonnene Revision der Dogmen zu erleichtern und vermittelst genauerer historischer, mit philosophischem Geist angestellter, Untersuchungen bis auf die Quelle mehrerer Dogmen selbst zurück gehen und bestimmen zu können, was im N.T. als eigentliche Lehre Jesu dargestellt wird. ${ }^{13}$

[This pragmatic presentation of late Jewish theology has been conducted (...) in order to facilitate the (presentation of the) revision of dogmas that began in our era (i.e., the Christian era).]

So far, we only have found the combination of "später" (i.e., "late") and “jüdisch" or Juden" (i.e., "Jews” or "Jewish"). But Poelitz uses the adjective "spätjüdisch" later on in his book, where he speaks of "spätjüdische Theologie" or "late-Jewish theology." 14 Consider his wording on page 287:

die Spuren der spätjüdischen Theologie sowohl im N.T. als auch in der ersten christlichen Kirche [sind] nicht $\mathrm{zu}$ verkennen.

[the traces of late-Jewish theology are clearly recognizable in the NT and in the early Christian church.]

From these two quotes, it is evident that Poelitz indeed limits the "spätere Juden" or "later Jews" to the pre-Christian era. He explicitly states that the "later Jews" ("spätern Juden") belong to the period "before the era of Jesus" ("die vor dem Zeitalter Jesu angetroffen wurde"), while describing the Jews after Christ as the "jüngern Juden nach Christo," meaning the "later Jews after Christ." ${ }^{15}$ Christ thus demarks the boundary between the earlier "later Jews" and the later "earlier Jews."

13 Poelitz, Pragmatische Uebersicht, 13.

14 Ibid., here 22 and 24.

15 Ibid., 8, 10. 


\section{Shifting Concepts of "Judentum" and its Internal History in the Nineteenth Century}

Poelitz's proposed designation of Second Temple Judaism as "späteres Judentum" was accepted in the early nineteenth century by, for instance, Heinrich Gottlieb Tzschirner, who adopted the term in his Vorlesungen über die christliche Glaubenslehre from 1829. Interestingly enough, the concept of "Spätjudentum" was even employed by Jewish thinkers of the nineteenth century. The rabbi of Braunschweig, Levi Herzfeld, used the adjective "spätjüdisch" to denote the era contemporaneous with Ezra in his History of the People of Israel from the Destruction of the First Temple to the Installation of the Maccabee Shimon to the Office of High Priest and Ruler. But the nineteenth century also saw some major general terminological shifts in the study of the history of Judaism. These shifts would be important for biblical scholarship. First, there is de Wette's influential differentiation between Hebraism and Judaism:

Wir nennen sie in dieser [sc. der nachexilischen] Periode Juden, vorher Hebräer, und was der nachexilischen angehört, Judenthum, die vorexilische hingegen Hebraismus. ${ }^{16}$

[We call them in this (postexilic) period "Jews," before that point, "Hebrews," and what belonged to the postexilic (period), "Judaism," whereas that which was preexilic was "Hebraism."]

De Wette explains what he calls "Judaism" as follows:

Das Judenthum ist die verunglückte Wiederherstellung des Hebraismus und die Mischung der positiven Bestandtheile desselben mit fremden mythologische-metaphysischen Lehren, worin ein reflectirender Verstand, ohne lebendige Begeisterung des Gefühls, waltet: ein Chaos, welches eine neue Schöpfung erwartet. Die charakteristischen Merkmale sind:

(1) Statt der sittlichen Richtung metaphysisches Nachdenken, und darin manche Fortschritte.

(2) Neben der mißverstandenen Symbolik eine schriftliche Religionsquelle, ohne selbständige Hervorbringungskraft.

(3) Während der Hebraismus Sache des Lebens und der Begeisterung war, ist das Judenthum Sache des Begriffs und des Buchstabenwesens. ${ }^{17}$

16 W. M. L. de Wette, Lehrbuch der christlichen Dogmatik, in ihrer historischen Entwickelung dargestellt: 1. Theil: Biblische Dogmatik Alten und Neuen Testaments oder kritische Darstellung der Religionslehre des Hebraismus, des Judenthums und Urchristentums, 3rd ed. (Berlin: Reimer, 1831), 9.

17 Wette, Lehrbuch der christlichen Dogmatik, 114. 
[Judaism is the unsuccessful restoration of Hebraism, and the mix of its positive components with alien mythological-metaphysical teachings, in which a reflective understanding without living zeal of feeling presides: a chaos that waits for a new creation. The characteristic traits are:

1. In place of an ethical orientation, metaphysical reflection, and in this some improvements.

2. In addition to the misunderstood symbolism a written source of religion, without independent power to develop it.

3. While Hebraism was a matter of life and zeal, Judaism is a matter of concepts and literalism.]

As Ekkehard Stegemann has convincingly shown, de Wette's distinction was conducive to Christianity's adoption of the Old Testament as a product mainly of the "Hebrew" rather than the "Jewish" period of ancient Israel's history. ${ }^{18}$ For present purposes, it is especially important to see that de Wette pushed the beginning of Judaism back to the postexilic period. Therefore, there was no need for him to speak of "later Judaism": pre-Christian Judaism per se was "late Judaism."

Scholarly literature often portrays Julius Wellhausen as the villain who introduced the notion of "Spätjudentum" into scholarship. But this tendency is doubly wrong. First, we have seen that the concept is considerably older, going back to Poelitz. Second, Wellhausen never uses the substantive "Spätjudentum" (there are a few instances of the adjective).

Nevertheless, Wellhausen is responsible for another highly problematic differentiation within "Judaism" that has become nearly as influential as de Wette's distinction between "Hebraism" and "Judaism."

In Wellhausen's Israelitische und Jüdische Geschichte, he wrote:

Seine erstickende Wirkung hat es [sc. das Gesetz] erst allmählich ausgeübt; es dauerte lange, bis der Kern hinter der Schale verholzte. Bis auf den Pharisäismus blieben die freien Triebe in lebendiger Kraft, die von den Propheten ausgegangen waren; das ältere Judentum ist die Vorstufe des Christentums. ${ }^{19}$

[(The Law) exerted its suffocating effect only after some time. It took some time, until the kernel beneath the peel petrified. Except for the Pharisees, the free forces remained in lively

18 E. Stegemann, “Die Halbierung der 'hebräischen' Religion: De Wettes Konstruktion von 'Hebraismus' und 'Judentum' zum Zwecke christlicher Aneignung des Alten Testaments," in Wilhelm Martin Leberecht de Wette: Ein Universaltheologe des 19. Jahrhunderts, ed. H.-Peter Mathys and K. Seybold (Basel: Schwabe, 2001), 79-95.

19 J. Wellhausen, Israelitische und jüdische Geschichte (Berlin: Reimer, 1904), 203. 
vigour that had originated from the prophets. The more ancient Judaism is the predecessor of Christianity.]

The very last phrase of this quote is important for Wellhausen's inner differentiation of Judaism: The "more ancient" Judaism is the Judaism before the Pharisees. Vice versa this means that the era of the Pharisees is tantamount to "late Judaism" for him. But rather than the term "Spätjudentum," he uses the artificial German word "Judaismus" to denote what he conceives of as "late Judaism." In chapter 19 of his book, he describes "Die Ausbildung des Judaismus" or "The Formation of Judaism," 20 which he differentiates from the "Judentum vor der makkabäischen Periode"21 ["Judaism before the Maccabean period"] that, according to him, was "durchaus nicht so streng und ausschliesslich wie seitdem" ["not so strict and exclusive as from that point on"].

Wellhausen adopts de Wette's view of limiting Judaism ["Judentum"] to the postexilic period, but he differentiates the "more ancient Judaism" [“älteres Judentum"] during the pre-Maccabean period from the "Judaism" of the later period, which was formative for the Pharisaic movement. However, he did not, or at least not prominently, speak of this period in terms of "Spätjudentum," even though he occasionally employed the adjective "spätjüdisch." It is not difficult to see how the New Testament's polemical view of the "Pharisees" shaped the concept into a cliché in German Protestant scholarship of Wellhausen's time. Yet in his book Die Pharisäer und die Sadducäer: eine Untersuchung zur inneren jüdischen Geschichte, he tried to describe the Pharisees based on extrabiblical sources and mentioned the New Testament's distorted view of them. ${ }^{22}$

\section{Bousset's Notion of "Spätjudentum"}

The most prominent use of "Spätjudentum" appears in the era of the so-called "Religionsgeschichtliche Schule" ["History of Religions School"] at the turn of the twentieth century, especially in Göttingen. ${ }^{23}$ One of its champions was Wilhelm Bousset (1865-1920), who employed the term frequently and also ex-

20 Ibid., 254.

21 Ibid., 295.

22 J. Wellhausen, Die Pharisäer und die Sadducäer: eine Untersuchung zur inneren jüdischen Geschichte (Greifswald: Bamberg, 1974), 21.

23 Cf. G. Lüdemann and A. Özen, "Religionsgeschichtliche Schule," in Theologische Realenzyklopädie (Berlin: De Gruyter, 1997), 28:618-24. 
plained how he understood it. He is most explicit about "Spätjudentum" in his Jesu Predigt in ihrem Gegensatz zum Judentum:

Das Spätjudentum ist durchaus und ganz Pharisäismus und nichts weiter als Pharisäismus. $^{24}$

[Spätjudentum is thoroughly and completely Pharisaism and nothing other than Pharisaism.]

It becomes immediately clear that Bousset links up with Wellhausen here. Equating "Spätjudentum" with "Phärisäismus" is exactly what Wellhausen does in his Israelitische und jüdische Geschichte. If one continues reading in the literature of the time, another new aspect of the notion of "Spätjudentum" becomes apparent.

Es kann niemand entgehen, wie innig sich das Spätjudentum und der mittelalterliche Katholizismus berühren: dieselbe Äußerlichkeit, Werkgerechtigkeit, dieselbe Verbindung von Theologie und Juristerei, dieselbe Kasuistik..$^{25}$

[No one can miss how intimate the contact is between Spätjudentum and the Catholicism of the Middle Ages: the same formality, works righteousness, the same connection between theology and jurisprudence, the same casuistry.]

This quote is most remarkable because it shows that Protestant scholarship of the time was not only antisemitic in some respects, but also that what sometimes lay behind this antisemitism was hidden anti-Catholicism that only occasionally came to the surface.

The popularity of the term "Spätjudentum" in the early twentieth century becomes clear through its use even by Jewish scholars like Gershom Scholem, who spoke of "spätjüdische Apokalyptik" in a 1928 article. ${ }^{26}$ In his later letters, he comments correctly that the term "Spätjudentum" is a "skandalöse und beleidigende Terminologie"27 ["a scandalous and insulting terminology"], but he seems only to have made this assessment ex post.

24 W. Bousset, Jesu Predigt in ihrem Gegensatz zum Judentum (Göttingen: Vandenhoeck \& Ruprecht, 1892), 32.

25 E. von Dobschütz, Probleme des apostolischen Zeitalters (Leipzig: Hinrichs, 1904), 125.

26 G. Scholem, "Zur Entstehung der Kabbala," Korrespondenzblatt des Vereins zur Gründung und Erhaltung der Akademischen Wissenschaft des Judentums 9 (1928): 8.

27 G. Scholem, Briefe, Bd. 2: 1948-1970, ed. T. Sparr (Munich: Beck, 1995), 121. 


\section{The Abandonment of the Concept}

According to my investigation, unease regarding the notion of "Spätjudentum" appears first in Ernst Jacob’s review of a book by Albert Schweitzer:

Es soll nicht mit dem Verfasser [sc. Albert Schweitzer] darüber gerechtet werden, daß er dem schlechten Beispiel seiner Gewährsmänner folgt und das mit dem abwertenden Namen "Spätjudentum" benennt, was richtiger Frühjudentum heißen müßte. ${ }^{28}$

[We shall not dispute with the author (i.e., Albert Schweitzer) that he is following the bad example of his sources and pejoratively uses "Spätjudentum" for what would more correctly be called "Frühjudentum."]

At this early point, Jacob notes the pejorative nature of the term "Spätjudentum" and proposes "Frühjudentum" as a substitute. But his protest remained unheeded for decades, probably in part because it was written in a Jewish journal. The most decisive invocation against the term and concept of "Spätjudentum" came from Vienna, from Kurt Schubert, who clearly criticized the use of the term in his article in the second edition of the Lexikon für Theologie und Kirche from 1964:

Spätjudentum ist eine unrichtige, wenn auch stark eingebürgerte Bezeichnung für das Judentum der ntl. und talmudischen Zeit. ${ }^{29}$

[Late Judaism is an incorrect albeit very common term for Judaism in the New Testament and Talmudic period.]

Given the position of Ernst von Dobschütz, it is not surprising that the most effective protest against "Spätjudentum" came first from a scholar in Jewish studies, then from a Catholic writing for a Catholic encyclopedia, and finally from outside of Germany. Since the late 1960s, the term has been abandoned nearly without explanation. There were some further reverberations with the term "spätisraelitisch" ["late Israelite"] instead of "spätjüdisch" ["late Jewish"]. This terminology was popular with Klaus Koch, Odil Hannes Steck, and Ina WilliPlein, all of whom were "Professor für Altes Testament und spätisraelitische Religionsgeschichte" ["Professor for Old Testament and History of late Israelite Religion"] in Hamburg. Especially Martin Noth's influence lay behind the description "spätisraelitisch" instead of "spätjüdisch." Noth drew a link between the

28 E. Jacob, "Neue Literatur über Paulus und das Urchristentum," Monatsschrift für Geschichte und Wissenschaft des Judentums 75 (1931): 332.

29 K. Schubert, “Spätjudentum,” in Lexikon für Theologie und Kirche (Freiburg: Herder, 1964), 9:949. 
end of the history of Israel and the rejection of Christ in his "History of Israel" from 1950, titling chapter 34 "Die Ablehnung des Christus" ["The Rejection of the Christ"] $]^{30}$ and stating at the end of the chapter that "Die Geschichte Israels eilte danach schnell ihrem Ende zu." [“The history of Israel then hurried quickly to its end."] ${ }^{31}$ From this perspective, Judaism only began after the destruction of the Second Temple in 70 C.E.:

Was aus diesem Untergang "Israels" erwuchs, war jene Erscheinung, die wir als "Judentum" zu bezeichnen pflegen. ${ }^{32}$

[What grew out of this demise of "Israel” was the phenomenon that we call "Judentum."] ${ }^{33}$

I do not think that there are any serious scholars left out there who would still share this position. In my view, it has become abundantly clear that the question "when did Judaism begin?" does require a differentiated answer. One of the most convincing answers to that question was given, in my opinion, by Marc Brettler, in his article about "ancient Israelite Religion" and "Judaism." ${ }^{34}$ His answer is a good one, because it is nuanced and differentiated. When did Judaism begin? It depends on how you define Judaism. ${ }^{35}$ But 70 C.E. is certainly too late.

Konrad Schmid is professor of Hebrew Bible and Ancient Judaism at the University of Zurich. The literary history of the Pentateuch and the reconstruction of the redactional processes that led to its final shape constitute the main focus of his re-

30 M. Noth, Geschichte Israels (Göttingen: Vandenhoeck \& Ruprecht, 1950), 383-86.

31 Ibid., 386.

32 Ibid., 15.

33 Noth clarified that after 70 C.E., Judaism relied on earlier developments: "Dies alles [sc. die Arbeit der Rabbinen] ist hier nur eben anzudeuten und nicht genauer auszuführen; denn es gehört schon nicht mehr zur Geschichte Israels. In diesen Vorgängen konstituierte sich die neue Erscheinung des Judentums, gewiß in Fortführung schon längst, vor allem in der Diaspora, angebahnter Entwicklungen, aber doch so, daß es jetzt erst in der veränderten Situation seine besondere und bleibende Gestalt gewann." [All this (the work of the Rabbis) is only hinted at here and not explicated in detail because it does not belong to the history of Israel. In these events the new phenomenon of Judaism was constituted, certainly continuing elements long in development, especially in the Diaspora. Nonetheless, only in this altered situation did it take on its particular, lasting form.] Ibid., 399.

34 M. Brettler, "Judaism in the Hebrew Bible? The Transition from Ancient Israelite Religion to Judaism,” Catholic Biblical Quarterly 61 (1999): 429-47.

35 Cf. the detailed discussion of S. Mason, "Jews, Judaeans, Judaizing, Judaism: Problems of Categorization in Ancient History," Journal for the Study of Judaism 38 (2007): 457-512. For the discussion on the historical and intellectual significance of 70 C.E., see D. R. Schwartz and Z. Weiss, eds., Was 70 CE a Watershed in Jewish History? (Leiden: Brill, 2011). 
search. His main publications include Erzväter und Exodus: Untersuchungen zur doppelten Begründung der Ursprünge Israels in den Geschichtsbüchern des Alten Testaments (1999), Literaturgeschichte des Alten Testaments: Eine Einführung (2008), and Theologie des Alten Testaments (2019).

\section{Bibliography}

\section{Primary Sources}

Bietenhard, Hans. Die himmlische Welt im Urchristentum und Spätjudentum. Tübingen: Mohr Siebeck, 1950.

Boccaccini, Gabriele. Middle Judaism: Jewish Thought 300 B.C.E. to 200 C.E. Minneapolis: Fortress, 1991.

Bousset, Wilhelm. Jesu Predigt in ihrem Gegensatz zum Judentum. Göttingen: Vandenhoeck \& Ruprecht, 1892.

Cullmann, Oscar. Le milieu johannique: étude sur l'origine de l'evangile de Jean, sa place dans le judaïsme tardif, dans le cercle des disciples de Jésus et dans le christianisme primitif. Geneva: Labor et Fides, 1976.

von Dobschütz, Ernst. Probleme des apostolischen Zeitalters. Leipzig: Hinrichs, 1904.

Donaldson, Terry L. "Levitical Messianology in Late Judaism: Origins, Development, and Decline." Journal of the Evangelical Theological Society 24 (1981): 193-207.

Gaugler, Ernst. "Das Spätjudentum.” In Mensch und Gottheit in den Religionen: Kulturhistorische Vorlesung gehalten im Wintersemester, 277-313. Bern: Paul Haupt, 1943.

Hölscher, Gustav. Urgemeinde und Spätjudentum. Oslo: Dybwad, 1928.

Jacob, Ernst. "Neue Literatur über Paulus und das Urchristentum." Monatsschrift für Geschichte und Wissenschaft des Judentums 75 (1931): 328-35.

Jervell, Jacob. Imago Dei: Gen 1,26f. im Spätjudentum, in der Gnosis und in den paulinischen Briefen. Göttingen: Vandenhoeck \& Ruprecht, 1960.

Kittel, Gerhard. Die Probleme des palästinischen Spätjudentums und das Urchristentum. Stuttgart: Kohlhammer, 1926.

Morin de Blois, Jean. Commentarius historicus de disciplina in administratione sacramenti Poenitentiae tredecim primis seculis in ecclesia occidentali, ... Hic inserta sunt quae Judaei antiqui et recentiores tradunt de Poenitentia. Metelen: Frederici, 1682.

Noth, Martin. Geschichte Israels. Göttingen: Vandenhoeck \& Ruprecht, 1950.

Parente, F. "Escatologia e politica nel tardo giudaismo e nel cristianesimo primitivo." Rivista Storica Italiana 80 (1968): 234 -96.

Poelitz, Karl Heinrich Ludwig. Pragmatische Uebersicht der Theologie der spätern Juden. Leipzig: Feind, 1795.

Ringgren, Helmer. Israele: i padri, l'epoca dei re, il giudaismo. Milano: Edizione Jaca, 1987.

Rosso Ubigli, L. "Alcuni aspetti della concezione della 'porneia' nel tardo giudaismo." Henoch 1 (1979): 201- 45.

Schleiermacher, Friedrich D. E. Über die Religion: Reden an die Gebildeten unter ihren Verächtern. Studienausgabe. Zürich: TVZ, 2012. 
Scholem, Gershom. "Zur Entstehung der Kabbala." Korrespondenzblatt des Vereins zur Gründung und Erhaltung der Akademischen Wissenschaft des Judentums 9 (1928): 8.

Scholem, Gershom. Briefe, Bd. 2: 1948-1970. Edited by Thomas Sparr. Munich: Beck, 1995.

Schubert, Kurt. "Spätjudentum." In Lexikon für Theologie und Kirche, 9:949. Freiburg: Herder, 1964.

Wähner, Georg. Antiquitates Ebraeorum de Israeliticae gentis. Göttingen: Vandenhoeck \& Ruprecht, 1743.

Wellhausen, Julius. Israelitische und jüdische Geschichte. Berlin: Reimer, 1904.

Wellhausen, Julius. Die Pharisäer und die Sadducäer: eine Untersuchung zur inneren jüdischen Geschichte. Greifswald: Bamberg, 1974.

de Wette, Wilhelm Martin Leberecht. Lehrbuch der christlichen Dogmatik, in ihrer historischen Entwickelung dargestellt: 1. Theil: Biblische Dogmatik Alten und Neuen Testaments oder kritische Darstellung der Religionslehre des Hebraismus, des Judenthums und Urchristentums. 3rd ed. Berlin: Reimer, 1831.

\section{Secondary Sources}

Blum, Matthias. "Ich wäre ein Judenfeind?" Zum Antijudaismus in Friedrich Schleiermachers Theologie und Pädagogik. Vienna: Böhlau, 2010.

Brettler, Marc Zvi. "Judaism in the Hebrew Bible? The Transition from Ancient Israelite Religion to Judaism." Catholic Biblical Quarterly 61 (1999): 429-47.

Kusche, Ulrich. Die unterlegene Religion: Das Judentum im Urteil deutscher Alttestamentler. Berlin: Institut für Kirche und Judentum, 1991.

Legaspi, Michael C. The Death of Scripture and the Rise of Biblical Studies. Oxford: Oxford University Press, 2011.

Lüdemann, Gerd, and Alf Özen. "Religionsgeschichtliche Schule.” In Theologische Realenzyklopädie, 28:618-24. Berlin: De Gruyter, 1997.

Mason, Steve. "Jews, Judaeans, Judaizing, Judaism: Problems of Categorization in Ancient History." Journal for the Study of Judaism 38 (2007): 457-512.

Ritter, M. "Spätjudentum." In Historisches Wörterbuch der Philosophie, edited by Joachim Ritter, Karlfried Gründer, Gottfried Gabriel, and Rudolf Eisler, 9:1312-15. Basel: Schwabe, 1971-2007.

Schwartz, David R., and Zeev Weiss, eds. Was 70 CE a Watershed in Jewish History? Leiden: Brill, 2011.

Smend, Rudolf. "Schleiermachers Kritik am Alten Testament." In Epochen der Bibelkritik: Gesammelte Studien, vol. 3, edited by Rudolf Smend, 128-44. Munich: Kaiser, 1991.

Stegemann, Ekkehard. “Die Halbierung der 'hebräischen' Religion: De Wettes Konstruktion von 'Hebraismus' und 'Judentum' zum Zwecke christlicher Aneignung des Alten Testaments." In Wilhelm Martin Leberecht de Wette: Ein Universaltheologe des 19. Jahrhunderts, edited by Hans-Peter Mathys and Klaus Seybold, 79-95. Basel: Schwabe, 2001. 
